\title{
The slight impacts of marine current to Cd contents in bottom waters in Jiaozhou Bay
}

\author{
Dongfang Yang ${ }^{1,2,3, a}$, Xiuqin Yang ${ }^{1,2}$, Ming Wang ${ }^{1,2}$, Sixi Zhu ${ }^{1,2}$ and Fengyou \\ Wang ${ }^{1,2, b, c}$
}

${ }^{1}$ Research Center for Karst Wetland Ecology, Guizhou Minzu University, Guizhou Guiyang, Guizhou Guiyang, China;

${ }^{2}$ College of Chemistry and Environmental Science, Guizhou Minzu University, Shanghai, 550025, China;

${ }^{3}$ North China Sea Environmental Monitoring Center, SOA, Qingdao 266033, China.

adfyang_dfyang@126.com; ' ${ }^{b}$ Corresponding author; 'wangfy2001@yahoo.com.cn.

Keywords: Cd; Marine current; Major source; Slight impact; Jiaozhou Bay

\begin{abstract}
This paper analyzed the content, horizontal distribution and migration process of $\mathrm{Cd}$ in bottom waters in Jiaozhou Bay based on the investigation of Cd in July and October 1984. Results showed that $\mathrm{Cd}$ contents in bottom waters in July and October were $0.05-0.18 \mu \mathrm{g} \mathrm{L}^{-1}$ and $0.05-0.06$ $\mu \mathrm{g} \mathrm{L}^{-1}$, respectively, and were lower than the upper limit for Cd in Grade I $\left(1.00 \mu \mathrm{g} \mathrm{L}^{-1}\right)$ in Sea water quality standard (GB 3097-1997) of China. Cd contents in July were decreasing from the inside of the bay mouth to the bay mouth, and then the outside of the bay mouth. Cd contents in October were decreasing from the outside of the bay mouth to the bay mouth; and the inside of the bay mouth to the bay mouth in October. The reasons of the sedimentation rates of $\mathrm{Cd}$ were different were that high $\mathrm{Cd}$ contents were occurring in different areas in surface waters, and the vertical water's effect. In generally, Marine current was the major source, whose impacts on Cd contents were very slight in 1984 .
\end{abstract}

\section{Introduction}

$\mathrm{Cd}$ is one of the critical heavy metal which has been widely used both industry and agriculture. A lot of Cd-containing waste water was generated and discharged to the environment, including marine bay [1-2]. Once the ocean has been polluted bay $\mathrm{Cd}$, whose marine current could be one of the Cd source [3-7]. Jiaozhou Bay is a semi-closed bay in Shandong Province, China, and has been long suffering from anthropogenic pollution due to the environmental protection was lagging from the rapid developing of agriculture, industry and urbanization [3-7].

This paper analyzed the content, distribution and migration of $\mathrm{Cd}$ in bottom waters in Jiaozhou Bay based on investigation data of $\mathrm{Cd}$ in 1984. We found that the major source of Cd was marine current, and we assessed the impacts of marine current to $\mathrm{Cd}$ contents in bottom waters. These founding would be helpful to understand the background pollution level of $\mathrm{Cd}$ in the beginning stage of the reform and opening-up, as well as the research on the existence and migration of $\mathrm{Cd}$ in bottom waters in Jiaozhou Bay.

\section{Materials and method}

Jiaozhou Bay is located in the south of Shandong Province, eastern China $\left(35^{\circ} 55^{\prime}-36^{\circ} 18^{\prime} \mathrm{N}\right.$, $120^{\circ} 04^{\prime}-120^{\circ} 23^{\prime} \mathrm{E}$ ), and is connected to the Yellow Sea in the south. The total area, average water depth and bay mouth width are $446 \mathrm{~km}^{2}, 7 \mathrm{~m}$ and $3 \mathrm{~km}$, respectively. This bay is a typical of semi-closed bay. There are a dozen of inflow rivers, and the majors are Dagu River, Haibo Rriver, Licun Rriver, and Loushan Rriver etc., all of which are seasonal rivers [8-9].

The investigation on Cd in bottom waters in Jiaozhou Bay was carried on in July and October 1984 in three investigation sites namely 2031, 2032 and 2033, respectively (Fig. 1). Cd in bottom waters was sampled and monitored follow by National Specification for Marine Monitoring [10]. 


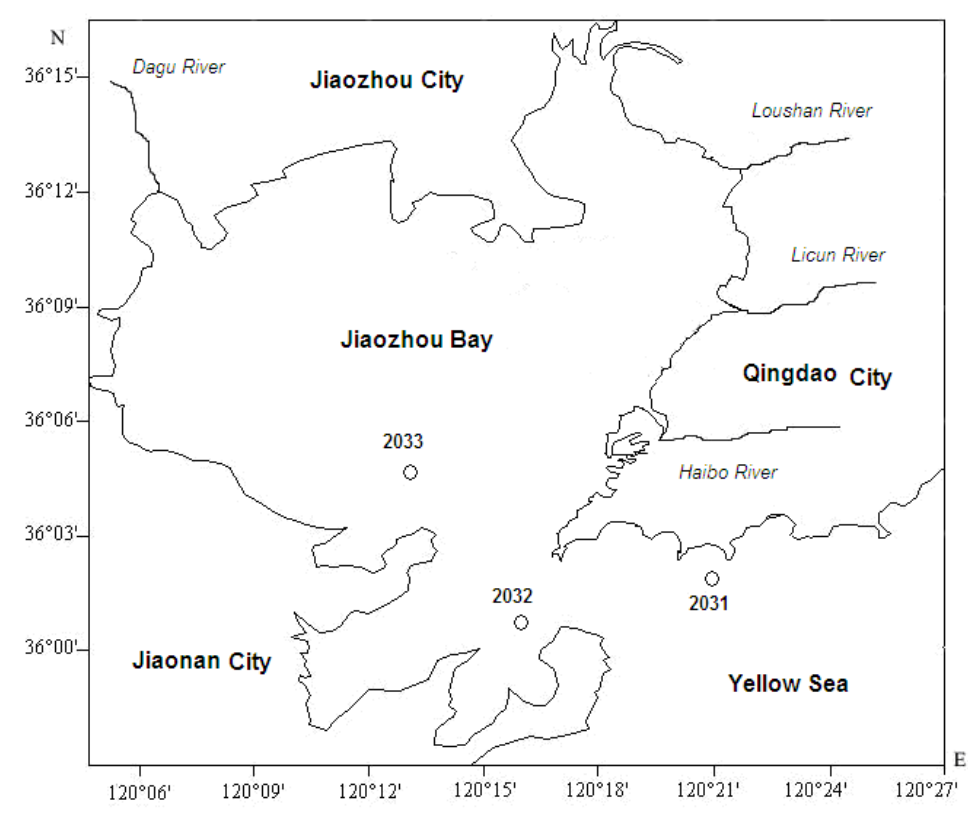

Fig.1 Investigation sites in Jiaozhou Bay

\section{Contents of $\mathrm{Cd}$ in bottom waters}

$\mathrm{Cd}$ content in July and October in bottom water in Jiaozhou Bay in July and October 1984 were 0.05-0.06 $\mu \mathrm{g} \mathrm{L}^{-1}$ and 0.08-0.18 $\mu \mathrm{g} \mathrm{L}^{-1}$, respectively, and were lower than the upper limit for Cd in Grade I (1.00 $\left.\mathrm{g} \mathrm{L}^{-1}\right)$ in Sea water quality standard (GB 3097-1997) of China. July and October were summer and autumn in study area. Hence, it could be concluded that Cd contents in bottom waters were higher in autumn than in summer in Jiaozhou Bay. However, the pollution level of Cd in bottom waters in Jiaozhou Bay was still very low in 1984.

\section{Horizontal distribution of $\mathrm{Cd}$ in bottom waters}

Investigation Sites of 2031, 2032 and 2033 were located in the inside of the bay mouth, the bay mouth and the outside of the bay mouth, respectively. In July, high Cd contents were occurring in Site 2033 in the inside of the bay mouth (Fig. 2), and a series of parallel lines were forming between Site $2031\left(0.06 \mu \mathrm{g} \mathrm{L}^{-1}\right)$ and $2033\left(0.06 \mu \mathrm{g} \mathrm{L}^{-1}\right)$. Obviously, Cd contents were decreasing from the inside of the bay mouth to the bay mouth, and then the outside of the bay mouth in July. In October, high Cd contents were occurring in Site 2031 in the outside of the bay mouth, and a series of parallel lines were forming between Site $2031\left(0.18 \mu \mathrm{g} \mathrm{L}^{-1}\right)$ and $2033\left(0.08 \mu \mathrm{g} \mathrm{L}^{-1}\right)$. Cd contents were decreasing from the outside of the bay mouth to the bay mouth; and the inside of the bay mouth to the bay mouth in October.

\section{Migration process and source of $\mathrm{Cd}$ in bottom waters}

The contents of the substances in waters in Jiaozhou Bay are decreasing continuously by means of water exchange [11]. In July, Cd contents were lower than in October, and were increasing from the outside of the bay mouth to the bay mouth, and the inside of the bay mouth, indicating relative low sedimentation rate in the outside of the bay mouth and the bay mouth, yet relative high sedimentation rate in the inside of the bay mouth. While for October, Cd contents were relative high, and were decreasing from the outside of the bay mouth to the bay mouth, and the inside of the bay mouth to the bay mouth, indicating relative high sedimentation rate in the outside of the bay mouth and inside of the bay mouth, yet relative low sedimentation rate in the bay mouth. The reasons of the sedimentation rates of $\mathrm{Cd}$ were occurring in different areas were that high $\mathrm{Cd}$ contents were occurring in different areas in surface waters, and the vertical water's effect [10].

Marine current was only one of the major sources of Cd in Jiaozhou Bay. The source strength of $\mathrm{Cd}$ in July was relative low, and the low Cd contents could be transferred farther by marine current by means of vertical water's effect [10], leading to the relative high sedimentation rate in the inside of the bay mouth. On the contrary, Cd contents were relative high in October, and the relative high 
Cd content were transferred closer by marine current by means of vertical water's effect [10], leading to the relative high sedimentation rate in the bay mouth.

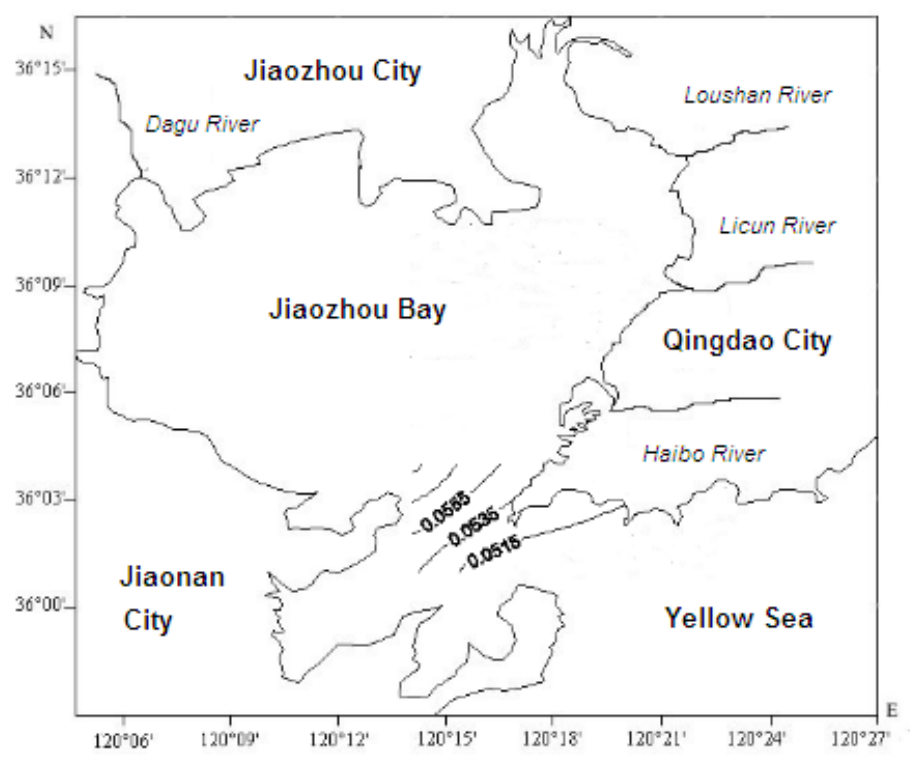

Fig. 2 Horizontal distributions of Cd in bottom waters of Jiaozhou Bay in July 1984/ $\mu \mathrm{g} \mathrm{L} \mathrm{L}^{-1}$

\section{Conclusion}

Cd content in July and October in bottom water in Jiaozhou Bay in July and October 1984 0.05-0.06 $\mu \mathrm{g} \mathrm{L}^{-1}$ and 0.08-0.18 $\mu \mathrm{g} \mathrm{L}^{-1}$, respectively, indicated the pollution level of Cd in bottom waters in Jiaozhou Bay was very low in 1984. In generally, Marine current was the major source, whose impacts on Cd contents were very slight in 1984. Cd contents in July were decreasing from the inside of the bay mouth to the bay mouth, and then the outside of the bay mouth in. Cd contents in October were decreasing from the outside of the bay mouth to the bay mouth, and the inside of the bay mouth to the bay mouth. Because of high $\mathrm{Cd}$ contents were occurring in different areas in surface waters, and by means of the vertical water's effect, the sedimentation rates of Cd were occurring in different areas.

\section{Acknowledgement}

This research was sponsored by Doctoral Degree Construction Library of Guizhou Nationalities University, Education Ministry's New Century Excellent Talents Supporting Plan (NCET-12-0659), the China National Natural Science Foundation (31560107) and Research Projects of Guizhou Nationalities University ([2014]02), Research Projects of Guizhou Province Ministry of Education (KY [2014] 266), Research Projects of Guizhou Province Ministry of Science and Technology (LH [2014] 7376).

\section{References}

[1] Yang DF and Miao ZQ: Marine Bay Ecology (I): Beijing, Ocean Precess, (2010), p. 1-320. (in Chinese)

[2] Yang DF and Gao ZH: Marine Bay Ecology (II): Beijing, Ocean Precess, (2010), p. 1-330. (in Chinese)

[3] Yang DF, Chen Y, Wang H, et al.: Coastal Engineering, Vol. 29 (2010), p. 73-82.

[4] Yang DF, Chen Y, Liu CX, et al.: Coastal Engineering, Vol. 32(2013), p. 68-78.

[5] Yang DF, Zhu SX, Wu YF, et al.: Applied Mechanics and Materials, Vols.644-650 (2014), p. 
5325-5328.

[6] Yang DF, Wang FY, Wu YF, et al.: Applied Mechanics and Materials, Vols.644-650 (2014), p. 5329-5312.

[7] Yang DF. Chen Y, Gao ZH, et al.: Proceedings of the 2015 international symposium on computers and informatics, (2015), p. 2667-2674.

[8] Yang DF, Chen Y, Gao ZH, et al.: Chinese Journal of Oceanology and Limnology, Vol. 23(2005), p. 72-90. (in Chinese)

[9] Yang DF, Wang F, Gao ZH, et al. Marine Science, Vol. 28 (2004), p. 71-74. (in Chinese)

[10]China's State Oceanic Administration: The specification for marine monitoring (Ocean Press, Beijiang 1991), p.1-300. (in Chinese) 